\title{
KOLABORASI MOTHERLY LEADERSHIP DAN PEMBELAJARAN DARING TERHADAP PENINGKATAN CAPAIAN PERKEMBANGAN AUD DAN KEPUASAN WALI MURID AUD DI JAWA TIMUR
}

\author{
Nike Norma Epriliyana ${ }^{1)}$, Ratnasari Dwi Ade Chandra ${ }^{2, a)}$, Ade Irma Noviyanti ${ }^{3}$ \\ ${ }^{1,2,3)}$ Universitas PGRI Argopuro Jember, Jalan Jawa No.10, Jember, Indonesia \\ a)Email: ratnasaridwi082@gmail.com
}

\begin{abstract}
Abstrak
Penelitian ini terinspirasi dari kegiatan pembelajaran daring yang dilakukan sejumlah lembaga PAUD/TK/RA/IGRA selama pandemi Covid - 19. Penelitian ini bertujuan untuk mendeskripsikan bagaimana kolaborasi antara kepemimpinan motherly leadership kepala sekolah dan kegiatan pembelajaran daring yang diselenggarakan guru, akan dapat mempengaruhi tingkat capaian perkembangan AUD dan kepuasan wali murid AUD. Penelitian Deskriptif kuantitatif ini menggunakan analisis jalur. Responden berjumlah 350 yang terdiri dari guru dan wali murid pada 50 lembaga PAUD/TK/RA/IGRA yang tersebar di Jawa Timur yang terdiri dari Kabupaten Jember, Kabupaten Lumajang, Kabupaten Bondowoso, Kabupaten Situbondo dan Kabupaten Probolinggo. Teknik pengumpulan data dilakukan melalui angket yang disebar secara online. Hasil penelitian menyimpulkan bahwa secara kuantitatif, variabel motherly leadership (X1) berpengaruh secara langsung terhadap capaian perkembangan AUD (Z) yang ditunjukkan dengan t =0,986; sig.000. Variabel pembelajaran daring (X2) berpengaruh secara langsung terhadap capaian perkembangan AUD yang ditunjukkan dengan $\mathrm{t}=0,955$; sig. $=0,000$. Variabel motherly leadership $(\mathrm{X} 1)$ berpengaruh secara langsung terhadap kepuasan wali murid AUD (Y) yang ditunjukkan dengan $t=0,805$; sig.000. Variabel pembelajaran daring (X2) berpengaruh secara langsung terhadap kepuasan wali murid AUD (Y) yang ditunjukkan dengan $\mathrm{t}=0,776$; sig.000. Variabel capaian perkembangan AUD (Z) berpengaruh secara langsung terhadap kepuasan wali murid AUD (Y) yang ditunjukkan dengan t = 0,779; sig.000.
\end{abstract}

Kata kunci: Motherly Leadership, Pembelajaran Daring, Capaian Perkembangan AUD, Kepuasan Wali Murid

\begin{abstract}
This research was inspired by online learning activities carried out by PAUD/TK/RA/IGRA institutions during the covid-19 pandemic. This study aims to describe how the collaboration between motherly leadership of school principals and online learning activities organized by teachers will affect the AUD development and AUD parents satisfaction. This quantitative descriptive research used path analysis. There were 350 respondents consisting of teachers and AUD parents of 50 PAUD/TK/RA/IGRA institutions spread across East Java consisting of Jember Regency, Lumajang Regency, Bondowoso Regency, Situbondo Regency and Probolinggo Regency. Data collection techniques were carried out through questionnaires distributed online. The results of the study conclude that quantitatively, the motherly leadership variable (X1) has a direct effect on the AUD development $(Z)$ which is indicated by $t=$ 0.986; sig.000. The online learning variable (X2) has a direct effect on the AUD development as indicated by $t=0.955$; sig. $=0.000$. The motherly leadership variable (X1) has a direct effect on the AUD parents satisfaction $(Y)$ as indicated by $t=0.805$; sig.000. The online learning variable (X2) has a direct effect on the AUD parents satisfaction $(Y)$ as indicated by $t=0.776$; sig.000. The variable of AUD development $(Z)$ has a direct effect on the AUD parents satisfaction $(Y)$ which is indicated by $t=0.779$; sig.000.
\end{abstract}

Keywords: Motherly Leadership, Online Learning, AUD Development, AUD Parents Satisfaction 


\section{PENDAHULUAN}

Pandemi Covid - 19, telah merubah cara belajar siswa mulai dari tingkat pendidikan tinggi hingga pendidikan anak usia dini. Adanya regulasi Pemerintah terhadap kebijakan 5M (memakai masker, menjaga jarak, mencuci tangan, menghindari kerumunan, dan membatasi mobilitas), untuk meminimalisir penyebaran virus Covid - 19 membuat tenaga pendidik memiliki strategi untuk melaksanakan kegiatan pembelajaran di sekolah. Sejak pembelajaran tatap muka ditiadakan, kegiatan pembelajaran dilakukan dengan teknik pembelajaran online atau dikenal dengan pembelajaran daring. Menurut Asmuni (2020) pembelajaran daring adalah adalah suatu sistem rancangan pembelajaran dimana penerapannya menggunakan jaringan internet dan dilakukan secara tidak langsung antara guru maupun peserta didik, dengan waktu pembelajaran materi pembelajaran yang sama. Dalam kegiatan pembelajaran daring, guru mengirimkan teks, audio, gambar, animasi dan video streaming serta aplikasi yang berbasis website belajar yang digunakan melalui jaringan internet (Sri, 2014). Berbagai aplikasi yang digunakan diantaranya Zoom, Google Meet, Google Classroom, WhatsApp dan sebagainya.

Kegiatan pembelajaran daring tidak terlepas dari peran kepala sekolah yang berfungsi untuk memberikan pengarahan, pembimbingan, dan motivasi kepada guru untuk melaksanakan kegiatan pembelajaran daring. Aspek kepemimpinan kepala sekolah diharapkan dapat meenjadi jembatan penghubung antara guru, peserta didik dan walimurid sangat dibutuhkan. Kepala sekolah TK/PAUD umumnya adalah seorang perempuan/ibu dengan sikap yang dominan adalah kepedulian, pengayom, dan pemberi teladan. Gaya kepemimpinan seperti ini dinamakan Motherly Leadership.
Menurut Wiyani (2018) motherly leadership adalah praktik kepemimpinan yang dilaksanakan oleh kaum perempuan dengan berlandaskan pada karakternya sebagai seorang ibu. Karakter-karakter tersebut antara lain 1) Mandiri dan percaya diri; 2) Rajin dan kooperatif; 3) Sederhana dan peduli; 4) Jujur dan sopan; 5) Pengayom dan pemberi teladan. Gaya kepemimpinan motherly leadership dapat diterapkan dalam melaksanakan kegiatan pembinaan guru serta kegiatan pembelajaran yang melibatkan wali murid. Prinsip kepemimpinan motherly leadership yang harus doptimalkan diantaranya (1) meyakini dan mengamalkan pandangan bahwa memimpin itu melayani bukan mempengaruhi; (2) memposisikan diri sebagai pihak yang memberikan layanan kepadapelanggan internal maupun pelanggan eksternal; (3) menjadikan norma-norma yang berlaku di masyarakatnya sebagai landasan dalam mengoperasikan organisasi; menggerakkan anggota untuk bekerja dengan memberikan contoh atau teladan, bukan dengan memberikan instruksi; (5) bersikap positive responsive terhadap perubahan maupun kritikan.

Perbedaan kegiatan pembelajaran pada kondisi sebelum pandemi Covid - 19 dan setelah pandemi Covid - 19, pada akhirnya merubah juga tata laksana kegiatan pembelajaran. Sebelum pandemi Covid - 19, kegiatan pembelajaran yang dilakukan secara tatap muka disekolah, sepenuhnya merupakan tanggung jawab guru. Akan tetapi, berbeda dengan pembelajaran daring yang dilakukan pada masa pandemi. Dibutuhkan kolaborasi antara guru, wali murid dan kepala sekolah untuk saling berkoordinasi dalam kegiatan pembelajaran Anak Usia Dini (AUD). Adanya kegiatan pembelajaran secara daring diharapkan mampu untuk dapat meningkatkan capaian perkembangan AUD sesuai dengan usianya sehingga kepuasan wali murid AUD dapat terwujud. 
Idealnya, kegiatan pembelajaran yang dilaksanakan secara daring ataupun tatap muka tidak memiliki pengaruh yang berarti bagi capaian perkembangan AUD. Harapannya,meski di masa pandemi Covid - 19, AUD secara kognitif, afektif dan psikomotorik dapat berkembang sesuai dengan usianya. Kenyataan yang terjadi, berdasarkan temuan dari Wulandari dan Purwanta (2021) menyimpulkan bahwa sebagian besar capaian perkembangan anak mengalami penurunan selama pandemi Covid - 19. Aspek yang sangat besar memiliki penurunan adalah aspek sosial emosional, terutama lingkup prososial. Penurunan capaian perkembangan prososial dapat terjadi karena selama pembelajaran daring AUD tidak dapat melakukan interaksi sosial dengan orang lain khususnya guru dan teman-temannya (Toseeb, 2017). Untuk mencapai perkembangan prososial dibutuhkan interaksi yang responsif secara positif terhadap kebutuhan dan kesejahteraan orang lain. Capaian perkembangan AUD berdasarkan Permendikbud No. 137 Tahun 2014 dapat dilihat dari 6 aspek, yaitu (1) Nilai agama dan moral; (2) Fisik Motorik; (3) Kognitif; (4) Bahasa; (5) Sosial Emosional; dan (6) Seni.

Dalam upaya meningkatkan kualitas pembelajaran daring, diperlukan ketrampilan mengajar guru yang sesuai dengan kebutuhan. Diperlukan juga koordinasi yang baik antara kepala sekolah, guru, AUD dan wali murid. Wiyani (2018) dalam penelitiannya menyatakan bahwa kepuasan wali murid AUD dapat terwujud, apabila terdapat kesesuaian antara pelayanan pembelajaran guru terhadap AUD. Adanya pelayanan pembelajaran tidak terlepas dari kepemimpinan motherly leadership dari kepala sekolah, untuk membimbing, membina dan mengayomi guru.

Wali murid AUD merupakan pihak eksternal yang merasakan hasil dari sebuah pelayanan pendidikan, salah satu pelayanan pendidikan adalah dalam kegiatan pembelajaran. Dalam teori pemasaran, wali murid dapat diumpamakan sebagai konsumen atau pelanggan. Menurut Gasperz (2012) pelanggan adalah orang yang teramat penting dan harus dipuaskan kebutuhannya. Beberapa kriteria yang dapat dijadikan alat ukur kepuasan wali murid diantaranya : (1) karakteristik lebih cepat, yaitu pelayanan penyelenggaraan PAUD yang cepat, mudah dan nyaman; (2) karakteristik lebih murah, yaitu biaya penyelenggaraan PAUD yang terjangkau oleh wali murid; (3) karakteristik lebih baik, yaitu berhubungan dengan pelayanan penyelenggaraan pendidikan yang sesuai dengan peraturan/taat azas. Dengan adanya pelayanan pendidikan yang dapat memberikan kepuasan kepada wali murid, diharapkan akan menjadi salah satu sarana sosialisasi dan menjaga hubungan baik dengan pihak eksternal dalam jangka panjang. Sehingga citra baik darisebuah lembaga juga akan terwujud di masyarakat.Dampaknya adalah jumlah AUD yang menjadi muridakn semakin bertambah.

Telah menjadi harapan bersama bahwa adanya kepemimpinan motherly leadership dan kegiatan pembelajaran secara daring selama adanya pandemi Covid - 19, dapat bersinergi untuk tetap menjaga marwah pendidikan. Adanya pembelajaran daring, akan senantiasa tetap menjaga mutu pembelajaran agar capaian perkembangan AUD dapat terwujud, sehingga kepuasan wali murid dapat tercipta. Penelitian ini, mendeskripsikan bagaimana kolaborasi antara kepemimpinan motherly leadership kepala sekolah dan kegiatan pembelajaran daring yang diselenggarakan guru, akan dapat mempengaruhi tingkat capaian perkembangan AUD dan kepuasan wali murid AUD. 


\section{METODE PENELITIAN}

Penelitian ini terinspirasi dari kegiatan pembelajaran daring yang dilakukan sejumlah lembaga PAUD/TK dalam upaya memberikan pembelajaran kepada anak usia dini agar di masa pandemi, kegiatan pendidikan tidak terputus dan terabaikan. Penelitian ini menjelaskan tentang pengaruh gaya kepemimpinan motherly leadership kepala sekolah dan pembelajaran daring terhadap tingkat capaian perkembangan AUD dan kepuasan wali murid AUD. Penelitian ini termasuk penelitian deskriptif kuantitatif. Subyek penelitian adalah 50 lembaga TK/PAUD di Kabupaten Jember, Kabupaten Lumajang, Kabupaten Bondowoso, Kabupaten Situbondo dan Kabupaten Probolinggo yang menyelenggarakan kegiatan pembelajaran daring selama masa pandemi Covid - 19 . Responden terdiri dari guru, kepala sekolah dan wali murid dengan jumlah total 350 responden.

Pengumpulan data dilakukan dengan metode sebagai berikut : (1) Observasi yaitu dengan cara mendatangi secara langsung lokasi obyek penelitian dan mengobservasi kegiatan pembelajaran daring; (2) Wawancara yaitu dengan melakukan wawancara secara langsung kepada responden terkait kegiatan pembelajaran daring; (3) kuesioner yaitu dengan membagikan angket penelitian dan survey penelitian secara online untuk dijawab oleh responden. Variabel penelitian terdiri dari :

1. Motherly Leadership, diukur dari sikap kepala sekolah PAUD yang terdiri dari karakter mandiri dan percaya diri; rajin dan kooperatif; sederhana dan peduli; Jujur dan sopan; pengayom dan pemberi teladan

2. Pembelajaran Daring, diukur berdasarkan instrumen pembelajaran daring seperti rencana pembelajaran, media yang digunakan dan penilaian yang digunakan selama pembelajaran daring.
3. Tingkat Capaian Perkembangan AUD, diukur dari 6 (enam) aspek capaian perkembangan AUD meliputi nilai moral agama; fisik motorik; kognitif; bahasa; sosial emosional; dan seni.

4. Kepuasan Wali Murid AUD, diukur berdasarkan nilai kepuasan dengan instrumen karakteristik lebih cepat; karakteristik lebih murah; dan karakteristik lebih baik.

Teknik analisis data yang digunakan dalam penelitian adalah Analisis Jalur (Path Analysis) dengan variabel bebas Motherly Leadership (X1) dan Pembelajaran Daring (X2); variabel terikat adalah Kepuasan Wali Murid AUD (Y) dan variabel intervening adalah Tingkat capaian perkembangan AUD (Z). Secara konseptual dapat digambarkan sebagai berikut :

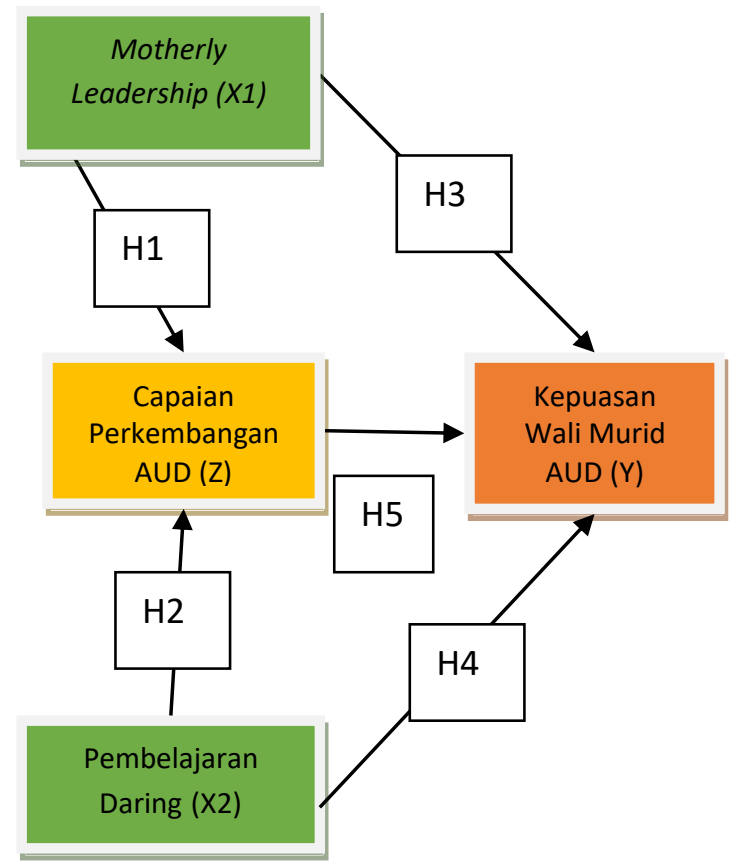

Gambar 1. Kerangka Konseptual

Rumus :

$Y=\beta 1 X 1+\beta 2 X 2$

$Y=\beta 1 X 1+\beta 2 X 2+\beta 1 Z 1$

Dimana :

$\mathrm{Y}=$ variabel terikat

$\mathrm{Z}=$ Variabel intervening

$\mathrm{X}=$ variabel bebas

$\beta=$ konstanta 
Berdasarkan jalur yang ada, penelitian ini menguji pengaruh secara langsung variabel motherly leadership (X1) dan pembelajaran daring (X2) terhadap Kepuasan Wali Murid AUD (Y). Penelitian juga menguji pengaruh variabel motherly leadership (X1) dan pembelajaran daring (X2) terhadap Kepuasan Wali Murid AUD (Y) melalui Capaian perkembangan AUD (Z). Hasil penelitian yang diperoleh dari jawaban responden akan dideskripsikan terlebih dahulu. Data dari responden yang diperoleh, akan diuji validitas dengan ketentuan nilai correlation $>0,3$ maka data dikatakan valid (Sarwono, 2014). Data kemudian diuji reliabilitas dengan ketentuan apabila nilai alpha cronbach $>0,6$, maka data dikatakan reliabel (Sarwono, 2014). Untuk menguji adanya pengaruh antar variabel, hasil jawaban responden akan diolah menggunakan SPSS ver.16.00. Setelah itu dilakukan pembahasan dan simpulan hasil penelitian.

\section{HASIL DAN PEMBAHASAN}

Pembelajaran daring yang dilaksanakan karena pamdemi Covid - 19 sebenarnya menimbulkan dilema dan kekhawatiran baik dari pihak kepala sekolah, guru dan wali murid. Adanya aspek capaian perkembangan AUD yang tidak dapat terpenuhi karena adanya pembelajaran daring akan menjadi pertimbangan dan penilaian tersendiri sebagai akibat yang ditimbulkan dari kegiatan pembelajaran daring. Penelitian ini, akan memaparkan beberapa aspek penyelenggaraan pembelajaran daring pada lembaga PAUD yang selama ini dilaksanakan oleh pihak lembaga. Berdasarkan hasil survey yang dilakukan peneliti, kegiatan pembelajaran daring di lembaga PAUD diselenggarakan dengan menggunakan gabungan aplikasi WhatsApp, Google Meet, Zoom dan Video pembelajaran via Youtube dengan persentase sebagai berikut:

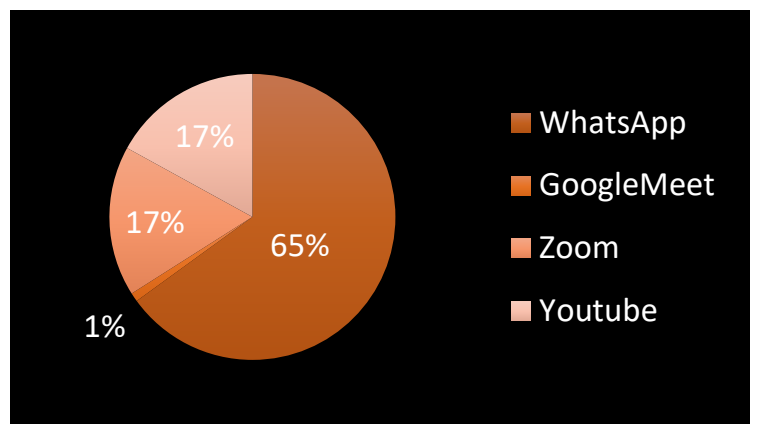

Gambar 2. Aplikasi Pembelajaran Daring yang Dilakukan Lembaga PAUD Selama Pandemi Covid - 19

Berdasarkan Gambar 1 diketahui bahwa kegiatan pembelajaran daring AUD dilaksanakan dengan menggunakan aplikasi WhatsApp sebesar 65\%; Google Meet sebesar 1\%; Zoom sebesar 17\% dan Youtube sebesar 17\%. Aplikasi WhatsApp banyak digunakan oleh guru karena mudah mengakses dan sebagian besar wali murid memiliki aplikasi tersebut. Aplikasi WhatsApp juga memudahkan wali murid dalam berkomunikasi dengan guru.

\section{Deskripsi Hasil Penelitian}

Berdasarkan proses pengumpulan data melalui penyebaran angket dan wawancara hasil penelitian dideskripsikan sebagai berikut :

\section{Motherly Leadership}

Kepemimpinan Motherly Leadership dari Kepala Sekolah, diukur dari aspek 1) Mandiri dan percaya diri; 2) Rajin dan kooperatif; 3) Sederhana dan peduli; 4) Jujur dan sopan; 5) Pengayom dan pemberi teladan. Hasil jawaban responden disajikan pada Gambar 3. Berdasarkan Gambar 3., responden yang dalam hal ini adalah guru memberikan penilaian terhadap gaya kepemimpinan Motherly Leadership yang diterapkan Kepala Sekolah. Sebesar 1,5\% Responden menjawab sangat tidak setuju bahwa Kepala Sekolah telah menerapkan kepemimpinan Motherly Leadership sesuai dengan teori; sebesar 2,5\% Responden menjawab tidak setuju bahwa Kepala 
Sekolah telah menerapkan kepemimpinan Motherly Leadership sesuai dengan teori; sebesar $14,3 \%$ responden menjawab cukup setuju bahwa Kepala Sekolah telah menerapkan kepemimpinan Motherly Leadership sesuai dengan teori; sebesar $52,8 \%$ responden menjawab setuju bahwa Kepala

Sekolah telah menerapkan kepemimpinan Motherly Leadership sesuai dengan teori; sebesar $28.9 \%$ responden menjawab sangat setuju bahwa Kepala Sekolah telah menerapkan kepemimpinan Motherly Leadership sesuai dengan teori. Berdasarkan responden yang menjawab terbanyak yaitu $52,8 \%$ menilai bahwa kepemimpinan Kepala Sekolah menggunakan Motherly Leadership, artinya sebagian besar responden menilai bahwa kepala sekolah di TK/PAUD/IGRA/RA menggunakan kepemimpinan yang mengutamakan aspek aspek Mandiri dan percaya diri; Rajin dan kooperatif; Sederhana dan peduli; Jujur dan sopan; Pengayom dan pemberi teladan.

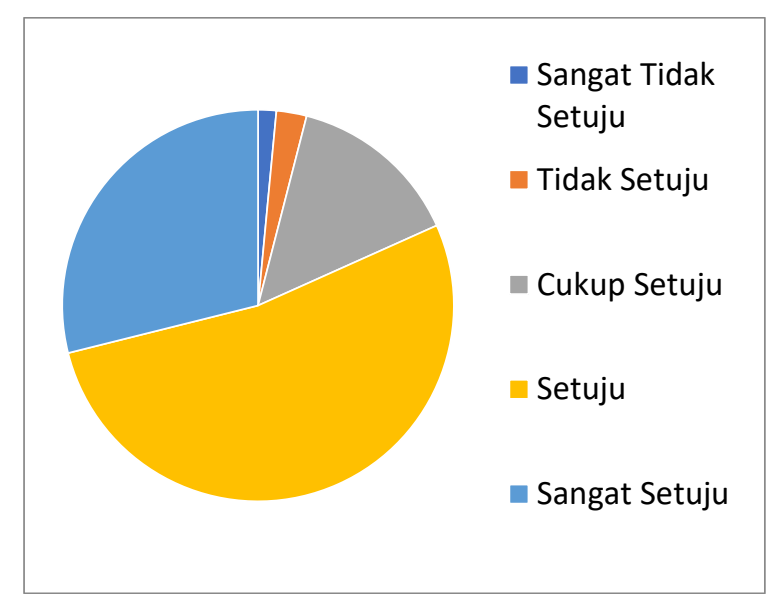

Gambar 3. Jawaban Responden terhadap variabel Motherly Leadership $\left(\mathrm{X}_{1}\right)$

\section{Pembelajaran Daring}

Pembelajaran daring diukur

berdasarkan instrumen pembelajaran daring seperti rencana pembelajaran, media yang digunakan dan penilaian yang digunakan selama pembelajaran daring. Hasil jawaban responden disajikan pada Gambar 4. Berdasarkan Gambar 4, responden yang dalam hal ini adalah guru memberikan penilaian terhadap kegiatan pembelajaran daring di lembaga. Sebesar $2,7 \%$ responden menjawab sangat tidak efektif kegiatan pembelajaran daring dilaksanakan; sebesar $12 \%$ responden menjawab tidak efektif bahwa kegiatan pembelajaran daring dilaksanakan; sebesar $38,5 \%$ responden menjawab cukup efektif pembelajaran daring dilaksanakan; sebesar $28,1 \%$ responden menjawab efektif bahwa kegiatan pembelajaran daring dilaksanakan; sebesar $18,7 \%$ responden menjawab sangat efektif bahwa kegiatan pembelajaran daring dilaksanakan. Berdasarkan responden yang menjawab terbanyak yaitu $38,5 \%$ menilai bahwa kegiatan pembelajaran daring cukup efektif dilaksanakan, Hasil jawaban dikarenakan adanya beberapa temuan kesulitan melaksanakan pembelajaran daring misalnya sulitnya jaringan internet, tidak adanya kuota belajar yang menjangkau lokasi, tidak semua wali murid memiliki smartphone utamanya untuk lembaga PAUD/TK/RA/IGRA di desa, sehingga harus mengambil tugas di lembaga. Pada saat pembelajaran daring AUD kurang berinteraksi dengan teman sekelas. Keluhan yang lainnya dirasakan oleh guru adalah selama kegiatan pembelajaran daring berlangsung, guru tidak bisa melakukan pengamatan terhadap perkembangan AUD. 


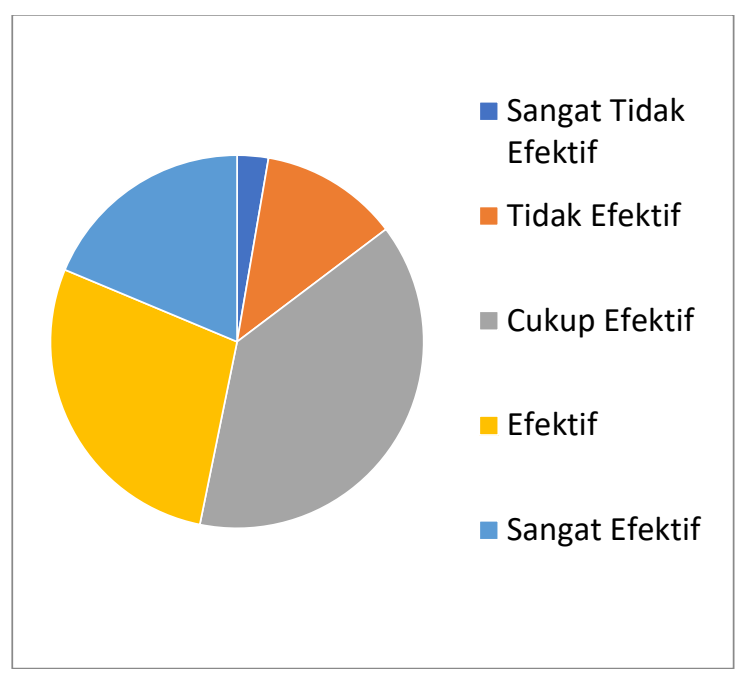

Gambar 4. Grafik Jawaban Responden terhadap variabel Pembelajaran Daring $\left(\mathrm{X}_{2}\right)$

\section{Capaian Perkembangan AUD}

Hasil deskripsi dari capaian perkembangan AUD diukur dari hasil jawaban responden terhadap 6 aspek perkembangan yang terdiri dari aspek nilai agama dan moral; fisik motorik; kognitif; bahasa; sosial emosional; dan seni.

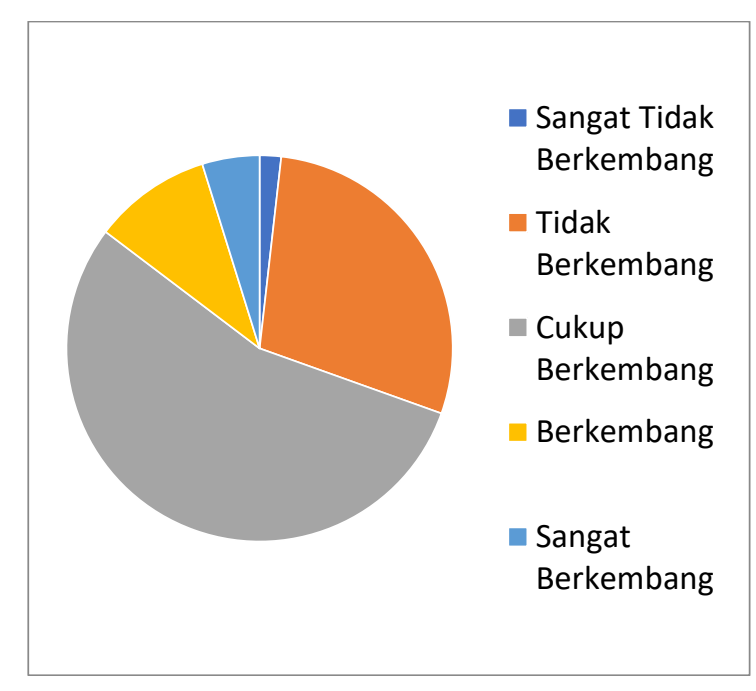

Gambar 5. Grafik Jawaban Responden terhadap variabel Capaian Perkembangan AUD (Z)
Hasil jawaban responden disajikan pada Gambar 5. Berdasarkan Gambar 5, sebesar $1,8 \%$ responden menjawab bahwa aspek capaian perkembangan AUD sangat tidak berkembang, sebesar $28,7 \%$ responden menjawab bahwa aspek capaian perkembangan AUD tidak berkembang, sebesar 54,8\% responden menjawab bahwa aspek capaian perkembangan AUD cukup berkembang, sebesar 9,9\% responden menjawab bahwa aspek capaian perkembangan AUD berkembang, sebesar 4,8\% responden menjawab bahwa aspek capaian perkembangan AUD sangat berkembang. Berdasarkan jawaban resonden yang tertinggi adalah $54,8 \%$ artinya melalui pembelajaran daring, capaian perkembangan AUD cukup berkembang. Ada aspek yang kurang berkembang selama daring misalnya fisik motorik dan sosial emosional karena AUD jarang berinteraksi dengan teman. Sedangkan aspek kognitif, nilai moral agama, bahasa, dan seni cukup berkembang. Guru mengalami kesulitan menilai capaian perkembangan AUD, karena selama pembelajaran daring anak didampingi oleh wali murid.

\section{Kepuasan Wali Murid}

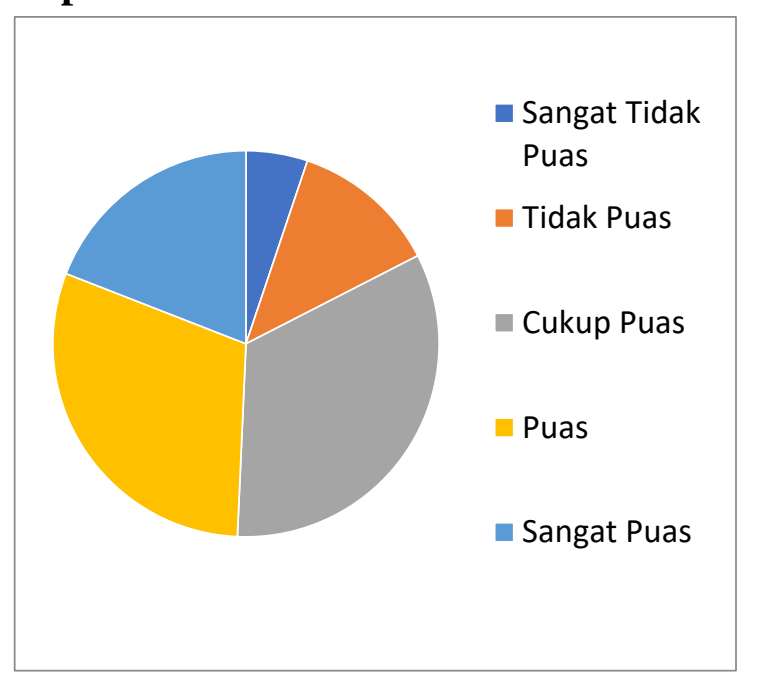

Gambar 6. Grafik Jawaban Responden terhadap variabel Kepuasan Wali Murid (Y) 
Kepuasan wali murid merupakan aspek penting dalam menilai keberhasilan pembelajaran daring. Kepuasan wali murid diukur instrumen karakteristik lebih cepat; karakteristik lebih murah; dan karakteristik lebih baik. Berdasarkan hasil jawaban responden pada Gambar 6., dapat dijelaskan bahwa sebesar $5,16 \%$ responden menjawab sangat tidak puas terhadap kegiatan pembelajaran daring; sebesar $12,3 \%$ responden menjawab tidak puas terhadap kegiatan pembelajaran daring; sebesar 33,25\% responden menjawab cukup puas terhadap kegiatan pembelajaran daring; sebesar 30,21\% responden menjawab puas terhadap kegiatan pembelajaran daring; dan sebesar $28,7 \%$ responden menjawab $19,08 \%$ responden menjawab sangat puas terhadap kegiatan pembelajaran daring. Ketidakpuasan wali murid muncul ketika dihadapkan pada dilema antara menemani AUD atau bekerja untuk mencari makan. Beragam latar belakang wali murid juga menjadi kendala kegiatan pembelajaran untuk mengajari AUD belajar.

\section{Hasil Analisis Jalur}

Dalam mengolah data menggunakan analisis jalur, jawaban responden yang telah diperoleh ditabulasi data, kemudian diuji validitas dan reliabilitas. Hasil uji validitas menunjukkan bahwa nilai correlation antara 0,308 - 0,899 artinya data yang diperoleh valid. Sedangkan hasil uji reliabilitas, nilai alpha cronbach penelitian yaitu antara 0,891 - 0,951, artinya data yang diperoleh reliabel. Data yang dihasilkan juga memenuhi uji normalitas yang ditunjukkan dengan penyebaran data mengikuti garis normal seperti Gambar 7. Maka data dapat dianalisis lebih lanjut melalui analisis jalur dengan menggunakan software SPSS ver. 16.00 .
Normal P-P Plot of Regression Standardized Residual

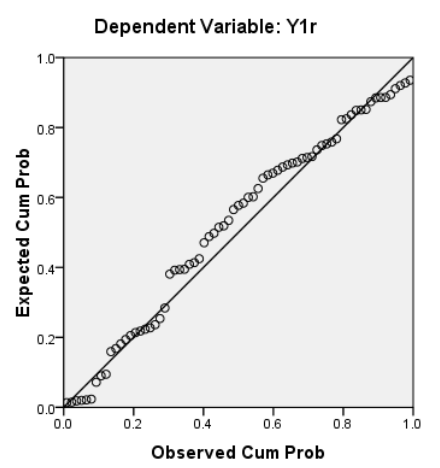

Gambar 7. Hasil Uji Normalitas Data

Berdasarkan hasil analisis jalur, model kolaborasi motherly leadership (X1) dan pembelajaran daring (X2) terhadap capaian perkembangan AUD (Z) dan kepuasan wali murid (Y) dapat dijelaskan sebagai berikut:

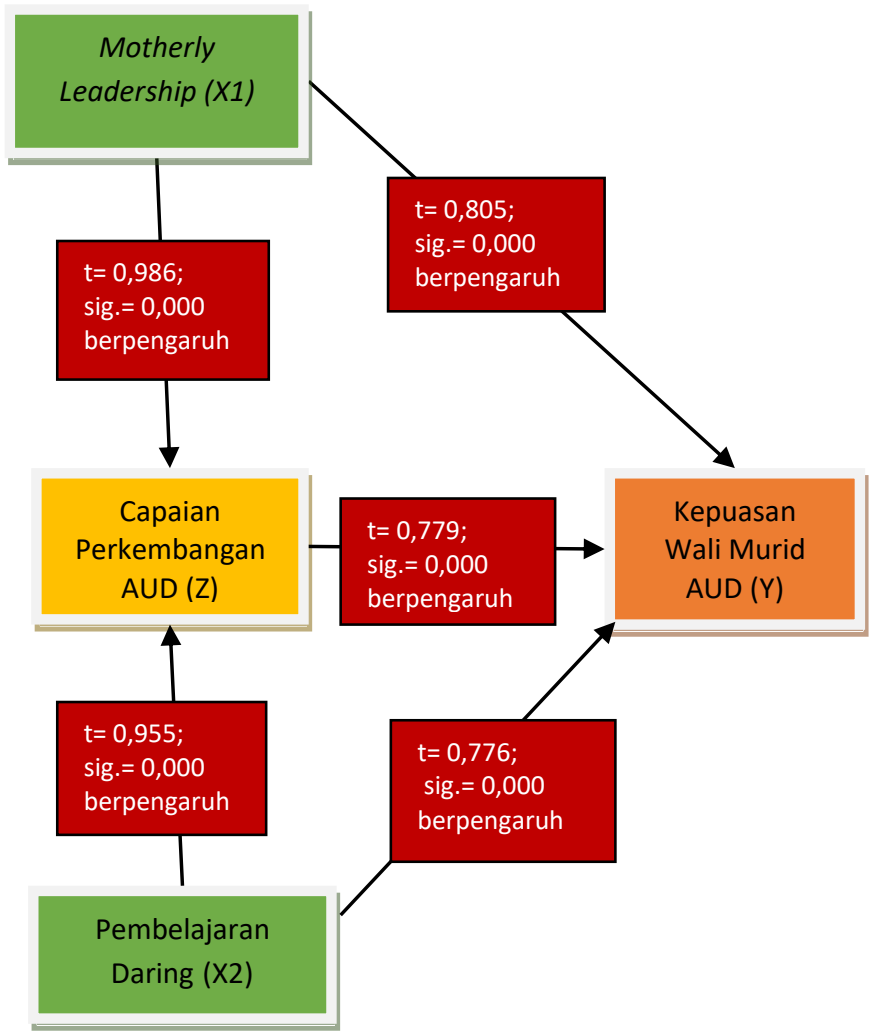

Gambar 8. Hasil Analisis Jalur Penelitian 
Gambar 8 menunjukkan bahwa secara kuantitatif, variabel motherly leadership (X1) berpengaruh secara langsung terhadap capaian perkembangan AUD (Z) yang ditunjukkan dengan $\mathrm{t}=$ 0,986; sig.000. Variabel pembelajaran daring (X2) berpengaruh secara langsung terhadap capaian perkembangan AUD yang ditunjukkan dengan $\mathrm{t}=0,955$; sig. $=$ 0,000. Variabel motherly leadership (X1) berpengaruh secara langsung terhadap kepuasan wali murid AUD (Y) yang ditunjukkan dengan $\mathrm{t}=0,805$; sig.000. Variabel pembelajaran daring (X2) berpengaruh secara langsung terhadap kepuasan wali murid AUD (Y) yang ditunjukkan dengan $\mathrm{t}=0,776$; sig.000. Variabel capaian perkembangan AUD (Z) berpengaruh secara langsung terhadap kepuasan wali murid AUD (Y) yang ditunjukkan dengan $\mathrm{t}=0,779$; sig. 000 .

\section{Pembahasan}

\section{Pengaruh Motherly Leadership (X1) terhadap Capaian Perkembangan AUD (Z)}

Variabel motherly leadership (X1) berpengaruh secara langsung terhadap capaian perkembangan AUD (Z) yang ditunjukkan secara kuatitatif dengan nilai $\mathrm{t}=0,986$; sig.000. Adanya pengaruh dapat dijelaskan bahwa kepala sekolah melalui gaya kepemimpinan yang dimilikinya, dapat memberikan motivasi, teladan, pengayom yang baik bagi guru. Dapat pula membuat guru lebih mandiri dan bertanggungjawab. Dengan demikian, akan berpengaruh terhadap kegiatan pembelajaran yang dilakukan oleh guru selama kegiatan pembelajaran daring. Apabila kegiatan pembelajaran sudah sesuai dengan instruksi kepala sekolah, maka capaian perkembangan AUD agar berkembang sesuai dengan tahapan usia dapat tercapai. Hasil penelitian ini mendukung temuan dari Wiyani (2018) yang menyatakan bahwa kepemimpinan kepala sekolah memberikan dampak terhadap kinerja guru melalui kegiatan pembelajaran.

2. Pengaruh Pembelajaran Daring (X2) terhadap Capaian Perkembangan AUD (Z)

Variabel pembelajaran daring (X2) berpengaruh secara langsung terhadap capaian perkembangan AUD yang ditunjukkan dengan $\mathrm{t}=0,955$; sig. $=0,000$. Adanya pengaruh dapat dijelaskan bahwa dalam proses pembelajaran daring, guru telah melakukan berbagai persiapan mulai dari menyiapkan perangkat pembelajaran, pelaksanaan pembelajaran hingga penilaian hasil belajar AUD. Proses tersebut, sangatlah menentukan keberhasilan pembelajaran daring dengan harapan bahwa AUD dapat berkembang sesuai dengan tahapan usia. Akan tetapi, selama proses pembelajaran beberapa kendala dihadapi guru seperti kendala jaringan internet dan sulitnya menilai perkembangan AUD secara online, menyebabkan kegiatan pembelajaran daring kurang efektif. Hasil penelitian mendukung hasil temuan Wulandari dan Purwanta (2021) yang menyatakan bahwa sebagian besar capaian perkembangan AUD mengalami penurunan selama masa pandemi covid -19 .

3. Pengaruh Motherly Leadership (X1) terhadap Kepuasan Wali Murid (Y) Variabel motherly leadership (X1) berpengaruh secara langsung terhadap kepuasan wali murid AUD (Y) yang ditunjukkan dengan $\mathrm{t}=$ 0,805 ; sig.000. Hasil penelitian ini mendukung penelitian Wiyani (2018) dimana kepemimpinan motherly leadership yang menekankan pada karakteristik keibu - ibuan dapat diterapkan untuk memberikan pelayanan pendidikan untuk kepuasan wali murid AUD. 


\section{Pengaruh Pembelajaran Daring (X2) terhadap Kepuasan Wali Murid (Y) \\ Variabel pembelajaran daring} (X2) berpengaruh secara langsung terhadap kepuasan wali murid AUD ( $\mathrm{Y})$ yang ditunjukkan dengan $\mathrm{t}=$ 0,776 ; sig.000. Dapat dijelaskan bahwa proses yang dilakukan selama kegiatan pembelajaran daring menentukan tingkat kepuasan wali murid atas capaian perkembangan AUD. Hasil penelitian ini mendukung temuan dari Asmuni (2020) dan Sri (2021) yang menyatakan bahwa pembelajaran daring merupakan kegiatan pembelajaran yang didukung oleh perangkat secara online.

5. Pengaruh Capaian Perkembangan AUD (Z) terhadap Kepuasan Wali Murid (Y)

Variabel capaian perkembangan

AUD (Z) berpengaruh secara langsung terhadap kepuasan wali murid AUD (Y) yang ditunjukkan dengan $\mathrm{t}=0,779$; sig.000. Hasil deskripsi penelitian menunjukkan bahwa apabila capaian perkembangan AUD sesuai dengan harapan wali murid, maka wali murid akan puas. Apabila capaian perkembangan AUD belum sesuai dengan harapan wali murid, maka wali murid tidak puas. Hal ini diperkuat oleh Gasperz (2012) pelanggan adalah orang yang teramat penting dan harus dipuaskan kebutuhannya.

\section{KESIMPULAN}

Berdasarkan Hasil penelitian, maka dapat diambil kesimpulan sebagai berikut :

1. Kepemimpinan dari Kepala Sekolah selama kegiatan pembelajaran daring berpengaruh terhadap pelaksanaan kegiatan pembelajaran daring dan tingkat kepuasan wali murid. Oleh karena itu, dibutuhkan sinergitas antara kepala sekolah, guru dan wali murid selama kegiatan pembelajaran daring untuk bersama - sama bekerjasama demi mencapai perkembangan AUD agar berkembang sesuai tahapan usia

2. Kegiatan Pembelajaran daring yang dilaksanakan tidak sepenuhnya efektif, karena menemui kendala diantaranya minimnya kuota, minimnya sinyal internet dan sulitnya guru melakukan penilaian secara langsung terhadap perkembangan AUD. Pembelajaran PTM terbatas merupakan salah satu solusi pembelajaran AUD di masa pandemi covid -19

3. Capaian perkembangan AUD harus diperhatikan karena sangat berpengaruh terhadap kepuasan wali murid. Besar harapan wali murid, setelah melaksanakan kegiatan pembelajaran daring, AUD dapat berkembang sesuai dengan tahapan usianya.

4. Kepuasan wali murid dipengaruhi oleh lancarnya kegiatan pembelajaran daring, kepemimpinan kepala sekolah dan capaian perkembangan AUD yang berkembang sesuai dengan tahapan usia.

\section{UCAPAN TERIMA KASIH}

Ucapan terima kasih Kami sampaikan kepada LPPM Akademi Akuntansi PGRI Jember dan LPPM IKIP PGRI Jember atas ijin yang diberikan untuk melaksanakan kegiatan penelitian. Terima kasih Kami sampaikan kepada wali murid, Bapak dan Ibu Kepala Sekolah dan Guru seluruh TK/RA/PAUD/IGRA di wilayah Kabupaten Jember, Kabupaten Lumajang dan Probolinggo yang menjadi responden dalam penelitian ini. Semoga hasil penelitian dapat menjadi sumbangsih terhadap kekayaan khasanah ilmu pengetahuan dan pengelolaan kegiatan pembelajaran pada TK/PAUD/RA/IGRA 


\section{DAFTAR PUSTAKA}

Asmuni, A. (2020). Problematika Pembelajaran Daring di Masa Pandemi Covid-19 dan Solusi Pemecahannya. Jurnal Paedagogy, 7(4), 281. https://doi.org/10.33394/jp.v7i4.294 1.

Sarwono. (2014). SPPS 16.00 itu Mudah. Yogyakarta: Andi Offset.

Sri, K. U. (2014). E-Learning: Technological Development in Teaching for school kids. International Journal of Computer Science and Information Technologies, 5(5), 6124-6126.

Toseeb, U., Pickles, A., Durkin, K., Botting, N., \& Conti-Ramsden, G. (2017). Prosociality from early adolescence to young adulthood: A longitudinal study of individuals with a history of language impairment. Research in Developmental Disabilities, 62, 148159. https://doi.org/10.1016/j.ridd.2017.0 1.018 .

Yolanda \& Nasution. (2014). Pengaruh Kepemimpinan, Lingkungan Kerja dan Kompensasi terhadap Kinerja Guru dan Pegawai TK Hidayatullah Batam. Jurnal Equilibria. Vol 1., No.1. 2014.

Wiyani. (2018). Peningkatan Kepuasan Wali Murid pada Layanan PAUD melalui Praktik Motherly Leadership di KB ABACA Bumiayu. Jurnal Martabat, Vol. 2, No. 1 Juli 2018.

Wulandari, et al. (2021). Pencapaian Perkembangan Anak Usia Dini di Taman Kanak -Kanak selama pembelajaran daring di Masa Pandemi Covid - 19. Jurnal Obsesi: Pendidikan Anak Usia Dini, Vol 5 , No. 2, 2021. 